\title{
An Assessment of Engineering Students' Curricular and Co-Curricular Experiences and Their Ethical Development
}

\author{
Cynthia J. Finelli, Matthew A. Holsapple, Eunjong Raa, \\ Rob M. Bielby, Brian A. Burt, Donald D. CARPENTER ${ }^{\mathrm{b}}$, \\ TREVOR S. HARDING ${ }^{\mathrm{c}}$, AND JANEL A. SUTKUS ${ }^{\mathrm{d}}$ \\ University of Michigan, Republic of Korea ${ }^{a}$, Lawrence Technological University ${ }^{b}$, \\ California Polytechnic State University ${ }^{c}$, Carnegie Mellon University ${ }^{d}$
}

\section{BACKGROUND}

Ethics instruction is an important component of engineering undergraduate education, but little research has identified aspects of the undergraduate experience that contribute most to students' ethical development. Thus, an assessment of the impact of students' experiences on their ethical development is warranted.

\section{PuRPOSE (HyPOTHESIS)}

We apply a conceptual framework to the study of engineering students' ethical development. This framework suggests that both formal curricular experiences and co-curricular experiences are related to students' ethical development.

\section{DESIGN/MeTHOD}

Using survey data collected from nearly 4,000 engineering undergraduates at 18 institutions across the U.S., we present descriptive statistics related to students' formal curricular experiences and their co-curricular experiences. Additionally, we present data for three constructs of ethical development (knowledge of ethics, ethical reasoning, and ethical behavior).

\section{RESULTS}

For our sample, the quantity and quality of students' formal curricular experiences and their co-curricular experiences related to ethics was high. The levels of ethical knowledge and reasoning varied, as did ethical behavior.

\section{CONCLUSIONS}

Our data highlight opportunities for improving the engineering undergraduate/bachelor's level curricula in order to have a greater impact on students' ethical development. We suggest that institutions integrate ethics instruction throughout the formal curriculum, support use of varied approaches that foster high-quality experiences, and leverage both influences of co-curricular experiences and students' desires to engage in positive ethical behaviors.

\section{KEYWORDS:}

co-curriculum, curriculum, ethical development 


\section{INTRODUCTION}

The engineering profession requires the utmost ethical standards, and professional engineering societies across the globe are placing growing importance on ethics (e.g., Association of German Engineers, 2002; Canadian Engineering Qualifications Board, 2001; Engineers Australia, 2010; Japan Society of Civil Engineers, 1999; National Society of Professional Engineers, 2010; and Royal Academy of Engineering, n.d.). Many engineering colleges and programs consider this emphasis on ethics education to be an essential component of the undergraduate/bachelor's level curriculum (we will use the term undergraduate to refer to students pursuing a Bachelor of Science in Engineering degree), and colleges and universities have long made it a part of their missions to educate students about ethics. In fact, a recent study by the American Association of Colleges and Universities (2009) reveals that $59 \%$ of all campuses have goals related to ethical reasoning. The need to graduate engineers who have a keen sense of ethical and social implications of engineering work is further underscored in accreditation requirements. In the U.S., for example, standards established by ABET require that engineering graduates have "an understanding of professional and ethical responsibility" (ABET, 2009, p. 3), and these standards have resulted in an increase in students' awareness of ethics and professionalism (Prados, Peterson, \& Lattuca, 2005).

In spite of the importance placed on ethics education, numerous U.S. reports highlight the need to promote the ethical development of engineering students. The Carnegie Foundation's report Educating Engineers: Designing for the Future of the Field (Sheppard, Macatangay, Colby, \& Sullivan, 2009) makes a strong argument for a national effort to improve ethics education within the discipline. Similarly, the National Academy of Engineering's reports The Engineer of 2020 (2004) and Emerging Technologies and Ethical Issues in Engineering (2003), the National Science Foundation's strategic plan (2006), and the results of a series of engineering education research colloquia as reported in The Research Agenda for the New Discipline of Engineering Education (Adams, et al., 2006) call for improved ethics education.

Engineering colleges and programs have responded to this need to promote ethical development of engineering students by introducing ethics into curricula in a variety of ways, such as case studies, guest speakers, small group discussions, and in-class games (Colby \& Sullivan, 2008). However, there is no conclusive evidence about which of these myriad approaches is the most effective in influencing ethical development. For example, Haws (2001) concludes that a combination of theoretical grounding, case studies, and service-learning will optimize engineering ethics instruction, whereas other scholars advocate solely the use of case studies as the most effective technique (Bird, 2003; Harris, 2003). Some educators support prescribed techniques for making ethical decisions, similar to the approach often taken for an engineering design problem (Harris, 2003), while others warn of the "engineer-ization" of ethics (Newberry, 2004, p. 350) in which ethical dilemmas are presented as problems to be solved. And rather than advocating a given pedagogical technique, some researchers suggest including global and social issues in engineering as a key component of ethics instruction for engineers (Etter, Harding, Finelli, \& Carpenter, 2004; Herkert, 2003; Self \& Ellison, 1998).

Students' co-curricular experiences (e.g., participation in student organizations, project teams, or community service) supplement their formal instruction and have also been shown to be related to ethical development. Research has demonstrated that involvement in co-curricular experiences in general (Burt, et al., 2011), co-curricular experiences 
featuring diversity (Mayhew, Seifert, \& Pascarella, 2010), and co-curricular service activities (e.g., Boss, 1994; Pratt, 2001; Wright, 2001) can lead to increases in ethical development. However, there has been little widespread effort directed towards leveraging these experiences in the undergraduate curriculum.

To address the lack of clarity about effective curricular and co-curricular approaches, we have undertaken a multi-year, national research project to identify practices-in the formal curriculum as well as the co-curriculum - that most effectively promote ethical development of engineering undergraduate students. Our project involves 19 partner institutions across the U.S., 18 of which we visited to conduct interviews and focus groups with faculty, administrators, and students. We used the resulting qualitative data to develop the Student Engineering Ethical Development (SEED) Survey. This instrument assesses student characteristics, curricular and co-curricular experiences related to ethics, and three constructs of ethical development (i.e., knowledge of ethics, ethical reasoning, and ethical behavior). Using the SEED Survey, we collected data from 3,914 undergraduate engineering students at all class levels and from 18 diverse institutions across the U.S. - comprising the first large-scale, national dataset for the assessment of the ethical development of engineering undergraduates.

In this paper, we explain the conceptual framework for our study and describe the SEED Survey. We then present descriptive data from the SEED Survey and summarize and discuss our main findings. As it is beyond the scope of the paper, we will present a more comprehensive analysis of the SEED Survey data in later publications.

\section{Background and Theory}

We use a conceptual framework that is primarily based on Astin's (1993) InputsEnvironments-Outputs (I-E-O) model and Terenzini and Reason's (2005) adaptation of it. Astin's model has long served as an influential framework for studying students' college outcomes, and it posits that outputs are affected by two factors: inputs (a student's precollege characteristics and experiences) and environments (a student's experiences within his or her institution's specific environment).

Terenzini and Reason (2005) refined the model, broadened its scope, and demonstrated its utility for addressing a variety of college outcomes that include: academic competence (Reason, Terenzini, \& Domingo, 2006); social and personal competence (Reason, Terenzini, \& Domingo, 2007); ability to interact with diverse others (Reason, Cox, Quaye, \& Terenzini, 2010); and persistence (Reason, 2009). Other researchers have also used the framework to study outcomes in a range of contexts that include: sense of community and retention of first-year STEM students (Falls, 2009); spiritual development of first-year students (Lovik \& Volkwein, 2010); the effects of part-time faculty on first-year students (Eagen \& Jaeger, 2008; Jaeger \& Hinz, 2008); theological development in seminary students (Lincoln, 2009); and both engagement in civic and campus life and cultural competence of students living in residence halls (Murphy, 2010).

We adapt Terenzini and Reason's version of the I-E-O model and apply it to students' ethical development. As with the original I-E-O model (Astin, 1993), our conceptual framework (Figure 1) consists of factors corresponding to inputs, environments, and outputs, and it assumes that inputs and environments influence outputs. Additionally, it uses Terenzini and Reason's conceptualization of environment as comprising both organizational context and peer environment.

Inputs, as used in our framework, encompass student characteristics. These include precollege and in-college characteristics such as student demographics, high school 


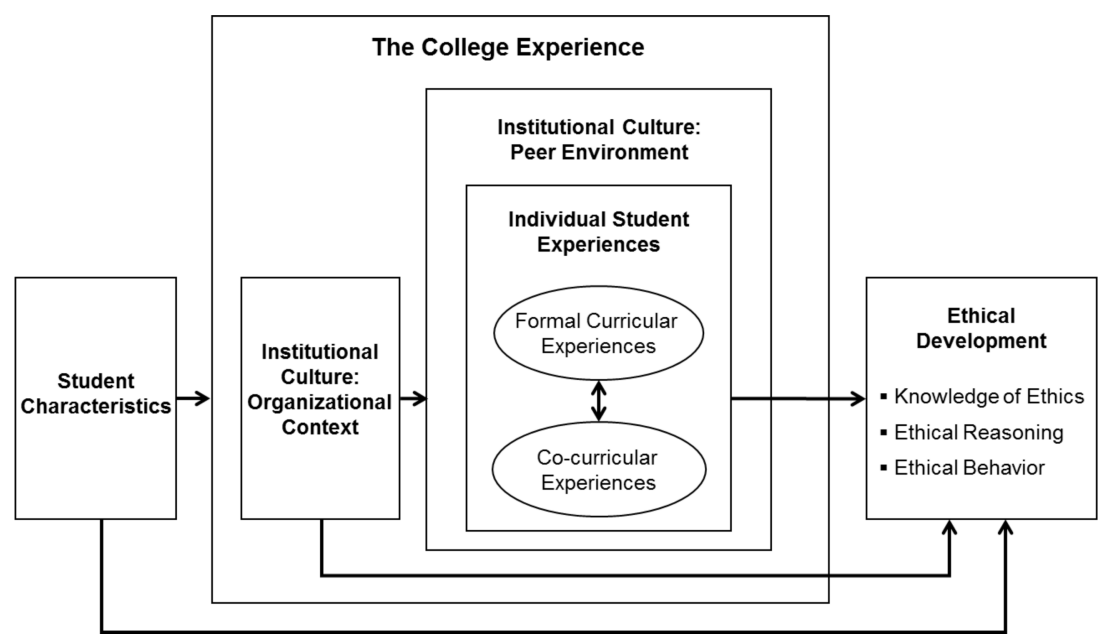

FIGURE 1. Conceptual framework of a student's ethical development during college.

behaviors, and other previous experiences. Environments involve both organizational context, which reflects program policies as well as values and practices of faculty and administrators, and peer environment, which is related to a campus' student body and includes such factors as dominant belief systems perceived by other students (Terenzini \& Reason, 2005). Considering that students may share a common peer environment, individual student experiences are depicted as nested within the peer environment. Further, reflecting that students' formal curricular experiences and their co-curricular experiences are separate yet related, these factors interact in our framework.

We conceptualize formal curricular experiences and co-curricular experiences in terms of both quantity and quality, considering them to be measures of student engagement. This conceptualization has ample support in the literature, as student engagement has been defined in various ways (Chen, Lattuca, \& Hamilton, 2008) that include: student participation in specific types of curricular and co-curricular activities and ways that institutions promote such participation (e.g., Kuh, 2001, 2003, 2009); the amount of time on task and associated level of effort in academic work, internships, co-curricular involvement, or student employment (e.g., Astin, 1993; Wolf-Wendel, Ward, \& Kinzie, 2009); and quality of effort on academic tasks (e.g., Pace, 1984, 1990). A common theme through these definitions is that engagement depends on both (1) the variety of curricular and co-curricular experiences and the amount of time students spend in them (i.e., quantity), and (2) the level of involvement in those experiences (quality).

Increases in student engagement have empirically been shown to result in increases in a broad range of student outcomes that include: academic achievement and intellectual development (Flowers, 2004; Kuh, Cruce, Shoup, Kinzie, \& Gonyea, 2008; Pike, 2003; Pike \& Kuh, 2005); cognitive complexity (Pascarella, Seifert \& Blaich, 2009); personal and social development (Bandura, Millard Peluso, \& Ortman, 2000; Flowers, 2004; Kuh, 1995); and persistence (Berger \& Milem, 1999; Hughes \& Pace, 2003; Kuh, et al., 2008; Tinto, 1993). The effect of curricular and co-curricular experiences on ethical development has also been examined, though co-curricular experiences have been studied less 
(King \& Mayhew, 2002). Higher levels of engagement with ethics instruction (Bonawitz, 2002; Mayhew \& King, 2008), diversity courses (Adams \& Zhou-McGovern, 1994; Hurtado, Mayhew, \& Engberg, 2003), service-learning (Bernacki \& Jaeger, 2008; Hoyt, 2008), and co-curricular activities that emphasize political debate and diversity (Mayhew, Seifert, \& Pascarella, 2010) have been shown to impact ethical development. Further, we previously demonstrated (Burt, et al., 2011) that co-curricular activities can improve students' ability to be thoughtful about ethical decisions, thus promoting ethical development.

As we define them, the outputs in our framework include three constructs of ethical development: knowledge of ethics, ethical reasoning, and ethical behavior. Though not defined in precisely the same way, others have operationalized these same constructs in the study of ethical development (Bebeau \& Thoma, 1999). Knowledge of ethics refers to a student's understanding of professional engineering codes of ethics (Keefer \& Ashley, 2001), and ethical reasoning refers to a student's ability to apply reason when identifying ethical options in professional engineering ethical dilemmas (Rest, Narvaez, Thoma, \& Bebeau, 2000). Ethical behavior refers to a student's ability to engage in behaviors consistent with his or her reasoned ethical decision, and we include both positive ethical behaviors (i.e., engaging in service activities (Penner, Dovidio, Piliavin, \& Schroeder, 2005)) and negative ethical behaviors (i.e., cheating in academic work (McCabe, 1997)) in our framework.

\section{Research Questions}

Relying on the well-established relationship between quantity and quality of students' experiences and a range of positive college outcomes, our purpose is to study ethical development of engineering undergraduate students using our conceptual framework as a guide and applying the lens of student engagement to describe individual student experiences. We present descriptive data to address three research questions:

- What is the quantity of curricular and co-curricular experiences related to ethics in which students are engaged?

- What is the quality of those experiences?

- What is the level of students' ethical development?

\section{The SEED Survey}

To establish a large-scale national dataset with which to study the ethical development of engineering undergraduates, we identified a diverse group of 19 partner institutions. We began by grouping all U.S., four-year, degree-granting engineering institutions into four categories based upon their Carnegie Classifications in the year 2007 (i.e., at the time of recruitment). We then ranked institutions in each category according to the combined number of students majoring in civil, electrical, or mechanical engineering, and-after making adjustments to maximize geographical diversity - we recruited the highest ranking institutions from each category. Combined, these 19 institutions accounted for $14 \%$ of the engineering bachelor's degrees awarded by all 339 engineering colleges in the U.S. in 2009-2010 (American Society of Engineering Education, 2010).

We visited 18 of our 19 partner institutions between the fall of 2007 and spring of 2010 to investigate institutional culture and other characteristics of each institution and to collect data to inform the design of a survey of ethical development. We reserved our 19th partner to be a pilot test site for our survey, so we did not visit that institution. For each visit, we conducted a student focus group (comprising students selected through a random 
recruitment process), a faculty focus group (comprising faculty identified by a campus liaison), and interviews with an academic administrator (such as an associate dean of undergraduate education) and a student affairs administrator (such as a director of student affairs). In total, 123 students, 110 faculty, and 36 administrators participated in the focus groups and interviews.

A comprehensive analysis of the qualitative focus group and interview data is ongoing. We have examined relationships between students' curricular and co-curricular experiences (Sutkus, Carpenter, Finelli, \& Harding, 2009) and differences in the perceptions of faculty, administrators, and students regarding ethics instruction (Holsapple, Carpenter, Finelli, Sutkus, Harding, \& Walczak, 2010; Holsapple, Carpenter, Sutkus, Finelli, \& Harding, 2012). Our analyses have also allowed us to identify possible obstacles in integrating ethics into the curriculum (Walczak, Finelli, Holsapple, Sutkus, Harding, \& Carpenter, 2010) and to explore the ethics-related outcomes of co-curricular involvement (Burt, et al., 2011).

In addition to conducting rigorous qualitative analysis of the focus group and interview data, we used those data to guide the development of our Student Engineering Ethical Development (SEED) Survey (Holsapple, Finelli, Carpenter, Harding, \& Sutkus, 2009; Sutkus, Finelli, Carpenter, \& Harding, 2008). Here, our analytic method differed from traditional qualitative methodology as we coded types of transcript data rather than focusing on discovering themes or drawing parallels or distinctions across institutional types. For instance, with regard to formal curricular experiences, we coded three types of data: (1) the kinds of activities participants describe as affecting ethical development, such as ethical case studies; (2) the pedagogy by which those activities were conducted, such as a case study presented by an actual participant in the case who asked students to reflect upon it and create their own ethically defensible solutions; and (3) the setting in which those activities were conducted, such as within a capstone engineering course.

From this analysis, we drafted the SEED Survey and tested it in three phases. First, we conducted cognitive interviews (Ericsson \& Simon, 1993; Van Someren, Barnard, \& Sandberg, 1994) in which students engaged in "think aloud" responses during one-onone interviews at two of our partner institutions. This allowed us to understand the way students interpret specific items and, in response, to rephrase our item wording appropriately. Second, we held two focus groups with other students at the same institutions to confirm the timing and length of the survey (administered in paper form) as well as to further establish the clarity of instructions and SEED Survey items. Third, after refining the instrument and adapting it into an online format, we administered it at the pilot institution to test our administration protocol and our online portal. This third phase of testing resulted in no changes to either our SEED Survey or our administration protocol, so we considered the data from our pilot institution to belong to our full dataset.

The final online SEED Survey (described in Table 1) includes 152 items plus a link to the online Defining Issues Test Version 2 (DIT-2; Rest, Narvaez, Bebeau, \& Thoma, 1999), an established instrument that assesses students' moral judgment. Combined, these items measure constructs of our conceptual framework including student characteristics, engagement in formal curricular and co-curricular experiences related to ethics, and ethical development.

Student characteristics. Twenty-one items on the SEED Survey measure student characteristics. These include items to assess student demographics, items in which respondents report their positive and negative ethical behavior in high school, and items to assess other previous experiences. 
Quantity and quality of formal curricular experiences. In our conceptual framework, we use the lens of student engagement to describe the impact of individual student experiences on ethical development. Consistent with this lens, our SEED Survey assesses both quantity and quality of curricular and co-curricular experiences related to ethics.

To assess the quantity of students' formal curricular experiences (i.e., the variety and number of their experiences), our SEED Survey presents respondents with a grid that addresses a range of approaches by which they may have encountered ethics instruction. The vertical axis of the grid represents nine different pedagogies (e.g., presentation by professor or role playing), while the horizontal grid axis defines distinct settings (e.g., introductory engineering course, out-of-class workshop, or senior design/capstone course). Because some course settings are only available to upper division students, first- and second-year students are presented with five distinct settings, while other students are presented with seven. Respondents mark all activities they have experienced.

\section{TABLE 1}

Items on the SEED Survey

Student characteristics

- Demographics: Class level, gender, race and ethnicity, age, specific engineering major, current college GPA, cumulative high school GPA, full-time/part-time status, previous educational experience, citizenship, primary language, and political orientation

- High school (i.e., secondary school) behavior: Participation in service in high school, cheating on tests in high school, or cheating on problem sets in high school

- Other previous experience: Participation in research with a faculty member, internship or co-op experience, full-time work, study abroad, or pre-college summer program

\section{Formal curricular experiences}

- For each of nine pedagogies (e.g., presentation by professor or role playing), items measuring settings in which it might have occurred (e.g., introductory engineering course, out-of-class workshop, or senior design/capstone course)

- For the most influential experience, the cognitive depth (using Bloom's taxonomy) and the likelihood of that experience impacting a future ethical decision

- Perception of importance of ethics instruction

- Satisfaction with quality of ethics instruction

Co-curricular experiences

- For each of five engineering activities (e.g., engineering design team or professional engineering student society) and ten non-engineering activities (e.g., student government, varsity athletics), items measuring

- frequency of participation

participation as an elected or appointed leader

participation in volunteer service of the group

\section{Ethical development}

- Knowledge of ethics: Ethics questions like ones on the Fundamentals of Engineering Examination

- Ethical reasoning: The PI, MN, P, and N2 scores on the DIT-2, calculated by the Center for the Study of Ethical Development

- Positive ethical behavior: Items about frequency of taking courses because of the community service component and participating in $\mathrm{K}-12$ outreach or volunteer service projects

- Negative ethical behavior: Items about frequency of cheating in college 
The SEED Survey also includes items about the quality of the formal curricular experiences. Respondents are asked to indicate the single curricular experience they would be most likely to consider when facing an engineering ethical dilemma - the "most influential" experience. For that experience, they select the cognitive activities in which they engaged from a list of options aligned with Bloom's taxonomy of educational objectives (Anderson \& Krathwohl, 2001; Bloom, 1956). The cognitive activities range from remembering facts or recognizing ethical concerns to critically evaluating the ethical decisions made by others or justifying one's own ethical decisions. We defined the cognitive depth of the most influential experience as the level of the highest cognitive activity marked. Finally, respondents indicate the importance of the ethics instruction they received and their satisfaction with it.

Quantity and quality of co-curricular experiences. To measure quantity of co-curricular experiences, our SEED Survey includes items we identified through our qualitative focus group and interview data as potentially influencing students' ethical development. Specifically, our survey includes five engineering activities (e.g., engineering design team or professional engineering student society) and ten non-engineering ones (e.g., student government or varsity athletics), and it asks students to indicate their frequency of participation in each of the 15 activities. Further, the focus group and interview data also indicated that the quality of students' involvement could be related to their participation both as a leader and in volunteer service through a given activity and that this, in turn, could influence their ethical development. Thus, the SEED Survey assesses both students' leadership involvement and volunteer service participation.

Ethical development. The SEED Survey assesses three constructs of ethical development: knowledge of ethics, ethical reasoning, and ethical behavior. We measure knowledge of ethics using students' responses to five ethics questions similar to those on the Fundamentals of Engineering (FE) Examination, administered by the National Council of Examiners for Engineering and Surveying (2010). Although it does not provide a perfect measure of ethical knowledge, many institutions use scores on the FE Examination as evidence of student learning in the accreditation process. Thus, we obtained permission from a popular FE Examination review manual (Potter, et al., 2008) to use published, FE-style ethics items in our SEED Survey.

To measure ethical reasoning, we use the Defining Issues Test Version 2 (DIT-2), the instrument most commonly used to assess the development of moral judgment (King \& Mayhew, 2002). Working with developers of the DIT-2, we used the first online version of the instrument in which respondents are presented with five separate moral dilemmas and asked to rank a series of statements in terms of their moral importance (Rest, Narvaez, Bebeau, \& Thoma, 1999). We use four variables from the DIT-2: the PI (Personal Interest); MN (Maintaining Norms); P (Post-conventional); and N2 scores. Each score provides information about the respondent's level of moral judgment, with lower PI scores and higher P and N2 scores indicating greater abilities to engage in cognitively complex moral reasoning. In college-aged students, national norms for the four scores are as follows (Bebeau, 2002): the PI score is typically in the range of 25-29, decreasing with age during college; $\mathrm{MN}$ scores are typically in the range of 32-34, with little change during college; $\mathrm{P}$ scores are often in the range of $32-38$, increasing with age during college; and the N2 score is typically in the range of 31-37 increasing with age during college.

Finally, we gauge ethical behavior with student reports of both positive and negative behaviors. Students indicate their level of engagement in five different service behaviors and seven different cheating behaviors. We use these items because we demonstrated that 
volunteering or participating in community service has content validity as a positive ethical behavior during the development stage of the instrument (Holsapple, et al., 2009) and because extensive research (e.g., McCabe, Trevino \& Butterfield, 2001), including more than ten years of our own work (e.g., Carpenter, Harding, Finelli, Montgomery, \& Passow, 2006; Finelli, Harding, Carpenter, \& Mayhew, 2007; Harding, Carpenter, Finelli, \& Passow, 2004a; 2004b; Harding, Finelli, \& Carpenter, 2006, 2012), has established cheating as a valid measure of negative ethical behavior. Note that, though involvement in volunteer service through a co-curricular activity could also be considered a positive ethical behavior, we use this variable as an indication in co-curricular participation.

\section{Data and Results}

Using a rolling recruitment procedure, we invited a stratified (by class year and institution) random sample of 17,344 engineering undergraduates at 18 partner institutions to participate in our study. In all cases, proper human subject research protocols were implemented and reviewed for compliance by each partner institution. As the survey was quite long, students who submitted our online survey were given a $\$ 20$ Amazon.com Gift Card for their participation. A total of 3,914 completed the SEED Survey, resulting in a response rate of $23 \%$. Table 2 shows student recruitment and response data, by institution category.

Tables 3 through 7 present data from the survey. Here, we present descriptive data for variables of our conceptual framework including: student characteristics; quantity and quality of curricular and co-curricular experiences related to ethics; and all three constructs of ethical development.

\section{Student Characteristics}

Demographics. Table 3 shows that respondents to the SEED Survey are roughly equally distributed across class year, with a somewhat greater proportion of first year students responding (33\%). Females comprise $22 \%$ of the population, and minorities historically underrepresented in engineering in the U.S. (i.e., respondents who identify as a member of one or more of the following categories: American Indian/Alaskan Native; Black/African American; Native Hawaiian/Pacific Islander; and Hispanic) comprise 12\%

TABLE 2

SEED Recruitment and Response Data by Institution Category

\begin{tabular}{lccccc}
\hline $\begin{array}{l}\text { Carnegie Classification at } \\
\text { time of campus visit }\end{array}$ & $\begin{array}{c}\# \\
\text { institutions }\end{array}$ & $\begin{array}{c}\text { Undergraduate } \\
\text { engineering } \\
\text { enrollment[1] }\end{array}$ & $\begin{array}{c}\text { \# students } \\
\text { recruited }\end{array}$ & $\begin{array}{c}\text { \# SEED } \\
\text { responses }\end{array}$ & $\begin{array}{c}\text { Response } \\
\text { rate }\end{array}$ \\
\hline $\begin{array}{l}\text { Research University, Very } \\
\text { High Research }\end{array}$ & 6 & 32,984 & 5,952 & 1,369 & $23.0 \%$ \\
Other Research University & 5 & 12,443 & 5,972 & 974 & $16.3 \%$ \\
Master's University & 4 & 9,747 & 2,980 & 734 & $24.6 \%$ \\
$\begin{array}{l}\text { Baccalaureate or Special } \\
\text { Focus Institution }\end{array}$ & 4 & 3,312 & 2,440 & 837 & $34.3 \%$ \\
\hline Total & 19 & 58,486 & 17,344 & 3,914 & $22.6 \%$ \\
\hline
\end{tabular}

Note. [1] Engineering undergraduate enrollment data were collected from the American Society of Engineering Education (2010). 
TABLE 3

Student Characteristics: Percent of Respondents Marking Each Item

\begin{tabular}{|c|c|c|}
\hline \multirow{4}{*}{ Class level } & First year & $33 \%$ \\
\hline & Second year & $24 \%$ \\
\hline & Third year & $22 \%$ \\
\hline & Fourth year or more & $21 \%$ \\
\hline Gender & Female & $22 \%$ \\
\hline Race and ethnicity & Historically underrepresented minority [1] & $12 \%$ \\
\hline Age & & 20.4 years \\
\hline \multirow{12}{*}{ Engineering major } & Aerospace & $7 \%$ \\
\hline & Bioengineering or Biomedical & $8 \%$ \\
\hline & Chemical & $10 \%$ \\
\hline & Civil or Construction & $17 \%$ \\
\hline & Computer or Software & $16 \%$ \\
\hline & Electrical & $17 \%$ \\
\hline & Engineering, Eng Physics, and Eng Science & $3 \%$ \\
\hline & Environmental & $4 \%$ \\
\hline & Industrial or Manufacturing & $5 \%$ \\
\hline & Mechanical or Engineering Mechanics & $29 \%$ \\
\hline & Metallurgical, Materials, or Ceramic & $3 \%$ \\
\hline & Other [2] & $10 \%$ \\
\hline \multirow{4}{*}{$\begin{array}{l}\text { Current } \\
\text { college GPA }\end{array}$} & A & $38 \%$ \\
\hline & $\mathrm{B}$ & $46 \%$ \\
\hline & $\mathrm{C}$ & $13 \%$ \\
\hline & $\mathrm{D}$ or $\mathrm{F}$ & $1 \%$ \\
\hline \multirow{4}{*}{$\begin{array}{l}\text { Cumulative } \\
\text { high school GPA }\end{array}$} & A & $80 \%$ \\
\hline & $\mathrm{B}$ & $16 \%$ \\
\hline & $\mathrm{C}$ & $2 \%$ \\
\hline & $\mathrm{D}$ or $\mathrm{F}$ & $0 \%$ \\
\hline Full-time/part-time status & Full-time & $97 \%$ \\
\hline \multirow{3}{*}{ Previous educational experience } & Began at a different 4-year institution & $6 \%$ \\
\hline & Began at a 2-year/community college & $7 \%$ \\
\hline & Began at current institution & $86 \%$ \\
\hline Citizenship & U.S. citizen & $91 \%$ \\
\hline Primary language & English & $92 \%$ \\
\hline \multirow{3}{*}{ Political orientation } & Conservative & $32 \%$ \\
\hline & Neither liberal nor conservative & $30 \%$ \\
\hline & Liberal & $36 \%$ \\
\hline \multirow{3}{*}{$\begin{array}{l}\text { High school (secondary school) } \\
\text { behavior }\end{array}$} & Participated in service & $85 \%$ \\
\hline & Cheated on tests & $27 \%$ \\
\hline & Cheated on problem sets & $39 \%$ \\
\hline
\end{tabular}


TABLE 3

(Continued)

\begin{tabular}{|c|c|c|}
\hline \multirow{8}{*}{ Other previous experience } & Research with a faculty member for credit & $11 \%$ \\
\hline & .............. for pay & $5 \%$ \\
\hline & .............as a volunteer & $5 \%$ \\
\hline & ..............none & $78 \%$ \\
\hline & Internship or co-op experience & $25 \%$ \\
\hline & Full-time work & $6 \%$ \\
\hline & Study abroad & $6 \%$ \\
\hline & Pre-college summer program & $16 \%$ \\
\hline
\end{tabular}

Note. [1] For our purposes, historically underrepresented minorities are those respondents who identify as a member of one or more of the following categories: American Indian/Alaskan Native; Black/ African American; Native Hawaiian/Pacific Islander; and Hispanic. [2] Major categories which were marked by $2 \%$ or fewer of the overall sample were combined to create an "other" category. Contributing majors include: Agricultural; Architectural; Biological; Engineering Management; Geological; Mining; Naval Architectural and Marine; Nuclear and Radiological; Ocean; Petroleum; Surveying and Geomatics; and Other Major. Since students could mark multiple majors, the percentages do not total $100 \%$.

of the sample. The average age of the respondents is about 20 years. There is a diverse distribution among engineering majors: more than one-fourth of students are enrolled in mechanical or engineering mechanics (29\%), followed by civil or construction (17\%), electrical engineering (17\%), and computer or software (16\%). Almost half of the respondents (46\%) report having a current college GPA of 'B', while $80 \%$ had an 'A' in high school.

Nearly all respondents are full-time students (97\%), and most (86\%) began college at their current institution. Most report being U.S. citizens (91\%) and having English as the primary language (92\%). (Note that almost $10 \%$ of the respondents are international students who bring a different cultural perspective to their studies than U.S. citizens.) The political orientation of the respondents is fairly equally split between conservative (i.e., $32 \%$ ) and liberal (i.e., 36\%).

High school behavior. A large majority (85\%) of respondents participated in service activities at least once while they were in high school (i.e., secondary school). Far fewer report cheating on academic work during high school; $27 \%$ admit to cheating on tests and $39 \%$ admit to cheating on problem sets.

Other previous experience. A small fraction of the respondents have participated in research with a faculty member (11\% for academic credit, $5 \%$ for pay, and $5 \%$ as a volunteer), while $78 \%$ did not. One-quarter of the sample has participated in an engineering internship or co-op experience, $6 \%$ have at least one year of full-time work in an engineering firm, $6 \%$ have participated in a study abroad program, and $16 \%$ participated in a pre-college summer educational program prior to entering engineering.

\section{Quantity and Quality of Formal Curricular Experiences}

Quantity. Tables $4 \mathrm{a}$ and $4 \mathrm{~b}$ demonstrate the quantity (i.e., the variety and number) of formal curricular experiences in which respondents have experienced ethics instruction. Table 4a includes data for all students (a nine-by-five grid); while Table 4b includes data for upper division students (a nine-by-seven grid since only students beyond their second year were presented with the two pedagogies of "advanced engineering course" and "senior 
design/capstone course"). Overall, the quantity of formal curricular experiences is high. On average, respondents had 6.6 different types of formal curricular experiences (out of 45 possible, Table 4a), while upper division students had an average of 7.7 types of experiences (out of 63 possible, Table $4 b$ ).

As shown in Table 4a, presentation by a professor is the most common pedagogy of ethics instruction ( $84 \%$ of responses), followed by presentation by other (person speaking about his or her own experiences (66\%) or working engineer/guest speaker (59\%)) and discussion with classmates (59\%). An introductory engineering course is the most common setting in which students received ethics instruction (84\%), and out-of-class workshop and non-engineering course are the next most common settings (44\% for each).

TABLE $4 \mathrm{a}$

Quantity of Formal Curricular Experiences for All Respondents $(N=3,914)$

\begin{tabular}{|c|c|c|c|c|c|c|c|}
\hline & $\begin{array}{c}\text { Pre-college } \\
\text { program }\end{array}$ & $\begin{array}{l}\text { Introductory } \\
\text { engineering } \\
\text { course }\end{array}$ & $\begin{array}{l}\text { Out-of- } \\
\text { class } \\
\text { workshop }\end{array}$ & $\begin{array}{l}\text { Non- } \\
\text { engineering } \\
\text { course }\end{array}$ & Other & $\begin{array}{c}\text { Total for } \\
\text { this } \\
\text { pedagogy }\end{array}$ & $\begin{array}{l}\text { Average\# } \\
\text { settings in } \\
\text { which this } \\
\text { pedagogy was } \\
\text { experienced }\end{array}$ \\
\hline $\begin{array}{l}\text { Presentation by } \\
\text { professor }\end{array}$ & $8 \%$ & $73 \%$ & $19 \%$ & $16 \%$ & $4 \%$ & $84 \%$ & 1.2 \\
\hline $\begin{array}{l}\text { Presentation by } \\
\text { person speaking } \\
\text { about own } \\
\text { experiences }\end{array}$ & $6 \%$ & $44 \%$ & $26 \%$ & $10 \%$ & $6 \%$ & $66 \%$ & 0.9 \\
\hline $\begin{array}{l}\text { Presentation by } \\
\text { working } \\
\text { engineer/guest } \\
\text { speaker }\end{array}$ & $5 \%$ & $34 \%$ & $24 \%$ & $7 \%$ & $6 \%$ & $59 \%$ & 0.8 \\
\hline $\begin{array}{l}\text { Discussion with } \\
\text { classmates }\end{array}$ & $5 \%$ & $41 \%$ & $12 \%$ & $21 \%$ & $5 \%$ & $59 \%$ & 0.5 \\
\hline Movie or film & $3 \%$ & $26 \%$ & $7 \%$ & $14 \%$ & $5 \%$ & $43 \%$ & 0.6 \\
\hline Skit & $2 \%$ & $7 \%$ & $4 \%$ & $7 \%$ & $6 \%$ & $23 \%$ & 0.3 \\
\hline In-class game & $2 \%$ & $18 \%$ & $5 \%$ & $9 \%$ & $4 \%$ & $28 \%$ & 0.5 \\
\hline Role-playing & $2 \%$ & $23 \%$ & $7 \%$ & $9 \%$ & $5 \%$ & $40 \%$ & 0.5 \\
\hline Online modules & $2 \%$ & $17 \%$ & $5 \%$ & $8 \%$ & $6 \%$ & $30 \%$ & 0.4 \\
\hline $\begin{array}{l}\text { Total for this } \\
\text { setting }\end{array}$ & $15 \%$ & $84 \%$ & $44 \%$ & $44 \%$ & $19 \%$ & - & - \\
\hline $\begin{array}{l}\text { Average\# } \\
\text { pedagogies } \\
\text { experienced in } \\
\text { this setting }\end{array}$ & 0.6 & 4.8 & 2.0 & 1.9 & 0.9 & - & 6.6 \\
\hline
\end{tabular}

Note. Since every respondent was presented with nine pedagogies and five settings, this table presents data for 45 types of experiences. 


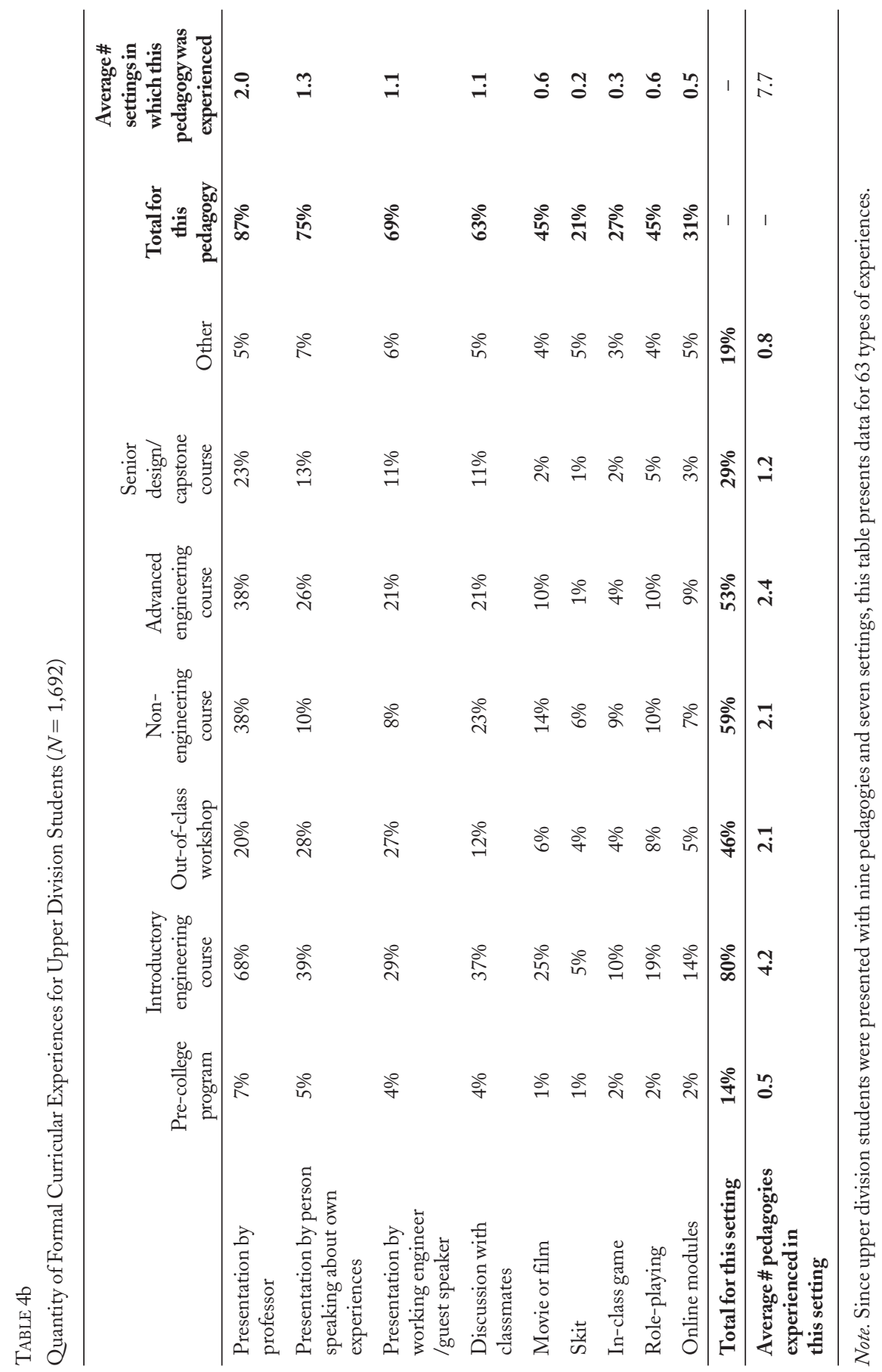


Table $4 \mathrm{~b}$ shows that presentation by professor remains the most common pedagogy for upper division students (87\%), followed by presentation by other (person speaking about his or her own experiences (75\%) or working engineer/guest speaker (69\%)) and discussion with classmates (63\%). The introductory engineering course is the most common setting (80\%), and out-of-class workshop and non-engineering course are also common (46\% and 59\%, respectively). A large percentage of upper division students reports also having ethics education in advanced engineering (53\%) and senior design/capstone courses (29\%).

The most common specific experience in the formal curriculum in which students receive ethics instruction (noted by $73 \%$ of the respondents) is presentation by professor in introductory engineering course (Table 4a). The four next most-highly noted individual experiences all occurred in the same setting: introductory engineering course. For upper division students (Table $4 \mathrm{~b}$ ), presentation by professor in introductory engineering experience remains the most common type of curricular experience (68\%), but presentation by professor in non-engineering course (38\%) or in advanced engineering course (38\%) are also common.

Quality. The SEED Survey also asks students to indicate the curricular experience they would be most likely to consider when facing an engineering ethical dilemma (Table 5). Presentation by professor is the most common pedagogy of that "most influential" experience (36\%), followed by presentation by other (person speaking about his or her own experiences (23\%) or working engineer/guest speaker (14\%)). For all respondents, the most common setting is an introductory engineering course (66\% for first- and second-year students and 33\% for upper division students), while advanced engineering course is also common (noted as the "most influential" experience by $26 \%$ of the upper division students).

In describing the cognitive depth of the "most influential" experience, nearly half of the respondents (47\%) report engaging in cognitive activities aligned with the highest level of Bloom's taxonomy of educational objectives - justify. Almost one in five (16\%) report being expected to evaluate ethical decisions in that curricular experience; while fewer than $10 \%$ report being expected to only apply information, recognize ethical concerns, or remember facts.

When reflecting on the "most influential" experience, only $43 \%$ of the respondents note that they would be likely to use that experience more than half the time when facing a future professional engineering ethics dilemma. Eighty-nine percent rate their learning about professional engineering ethics to be important or very important to their engineering education, and $86 \%$ are satisfied or very satisfied with the quality of education regarding professional engineering ethics at their institution.

\section{Quantity and Quality of Co-curricular Experiences}

Quantity. Table 6 presents data about participation in co-curricular activities. There is both a wide variety and high number of experiences. Eighty-eight percent report some type of co-curricular engagement, and respondents participated in an average of more than three of the 15 types of co-curricular experiences on the SEED Survey. The most common type of co-curricular activity is an engineering student organization based on major, discipline, or professional interests (70\%), followed by engineering design competition team (30\%), on-campus religious organization (29\%), engineering student organization focused on women (23\%), social fraternity or sorority (22\%), and leadership program or academy (20\%). 
TABLE 5

Quality of Formal Curricular Experiences

\begin{tabular}{|c|c|c|}
\hline \multirow{9}{*}{$\begin{array}{l}\text { Pedagogy of "most } \\
\text { influential" experience }\end{array}$} & Presentation by professor & $36 \%$ \\
\hline & Presentation by person speaking about own experiences & $23 \%$ \\
\hline & Presentation by working engineer/guest speaker & $14 \%$ \\
\hline & Discussion with classmates & $9 \%$ \\
\hline & Movie or film & $3 \%$ \\
\hline & Skit & $1 \%$ \\
\hline & In-class game & $1 \%$ \\
\hline & Role-playing & $5 \%$ \\
\hline & Online modules & $1 \%$ \\
\hline \multirow{4}{*}{$\begin{array}{l}\text { Setting of "most } \\
\text { influential" experience for } \\
\text { first-and second-year } \\
\text { students }(N=2,207)\end{array}$} & Pre-college program & $3 \%$ \\
\hline & Introductory engineering course & $66 \%$ \\
\hline & Out-of-class workshop & $16 \%$ \\
\hline & Non-engineering course & $7 \%$ \\
\hline \multirow{6}{*}{$\begin{array}{l}\text { Setting of "most } \\
\text { influential" experience } \\
\text { for upper division } \\
\text { students }(N=1,692)\end{array}$} & Pre-college program & $1 \%$ \\
\hline & Introductory engineering course & $33 \%$ \\
\hline & Out-of-class workshop & $15 \%$ \\
\hline & Non-engineering course & $9 \%$ \\
\hline & Advanced engineering course & $26 \%$ \\
\hline & Senior design/capstone course & $11 \%$ \\
\hline \multirow{7}{*}{$\begin{array}{l}\text { Cognitive depth } \\
\text { of "most influential" } \\
\text { experience }\end{array}$} & Justify the decision you would make & $47 \%$ \\
\hline & Critically evaluate the ethical decisions made by others & $16 \%$ \\
\hline & Identify information necessary to make ethical decision & $10 \%$ \\
\hline & Apply information learned to new ethical situations & $6 \%$ \\
\hline & Recognize ethical concerns faced by professional engineers & 9\% \\
\hline & Remember facts presented through this activity & $4 \%$ \\
\hline & None of the above & $9 \%$ \\
\hline \multicolumn{2}{|c|}{ Would use experience more than half the time in future } & $43 \%$ \\
\hline \multicolumn{2}{|c|}{ Perceive ethics instruction as important or very important } & $89 \%$ \\
\hline \multicolumn{2}{|c|}{ Are satisfied or very satisfied with quality of ethics instruction } & $86 \%$ \\
\hline
\end{tabular}

Note. These data describe characteristics of the single curricular experience respondents would be most likely to consider when facing an engineering ethical dilemma and respondents' overall perceptions of ethics instruction.

Quality. As described by participants in our focus groups and interviews, we relate quality of involvement in co-curricular experiences to both acting as a leader and participating in volunteer service sponsored by the group. In our sample, $34 \%$ of students were leaders, with the highest levels of leadership occurring in engineering organizations based on major, discipline, or professional interests $(12 \%)$ and in a social fraternity or sorority (10\%). Sixty-five percent of students report participating in volunteer service sponsored by the group, most commonly in engineering student organization based on major, discipline, or professional interests (34\%) and on-campus religious organization $(17 \%)$. 
TABLE 6

Quantity and Quality of Co-curricular Experiences

\begin{tabular}{|c|c|c|c|c|}
\hline & & $\begin{array}{c}\text { Participated } \\
\text { occasionally or } \\
\text { frequently } \\
\end{array}$ & $\begin{array}{c}\text { Acted as elected } \\
\text { or appointed } \\
\text { leader } \\
\end{array}$ & $\begin{array}{l}\text { Participated in } \\
\text { volunteer service } \\
\text { with group }\end{array}$ \\
\hline \multirow{7}{*}{ 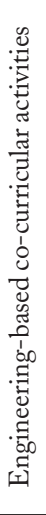 } & $\begin{array}{l}\text { Engineering student organization } \\
\text { focused on women }\end{array}$ & $23 \%$ & $4 \%$ & $13 \%$ \\
\hline & $\begin{array}{l}\text { Engineering student organization } \\
\text { focused on students of color }\end{array}$ & $13 \%$ & $2 \%$ & $7 \%$ \\
\hline & $\begin{array}{l}\text { Engineering student organization based } \\
\text { on major, discipline, or professional } \\
\text { interests }\end{array}$ & $70 \%$ & $12 \%$ & $34 \%$ \\
\hline & $\begin{array}{l}\text { Engineering student organization } \\
\text { focused on service }\end{array}$ & $19 \%$ & $3 \%$ & $12 \%$ \\
\hline & Engineering design competition team & $30 \%$ & $6 \%$ & $14 \%$ \\
\hline & Participated in at least one (five total) & $76 \%$ & $19 \%$ & $46 \%$ \\
\hline & $\begin{array}{l}\text { Average \# different types of experienc- } \\
\text { es per respondent (five total) }\end{array}$ & 1.5 & 0.3 & 0.8 \\
\hline \multirow{12}{*}{ 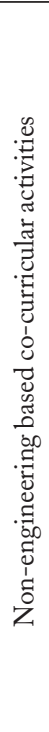 } & $\begin{array}{l}\text { Political organization or campaign, } \\
\text { other than student government }\end{array}$ & $13 \%$ & $2 \%$ & $7 \%$ \\
\hline & $\begin{array}{l}\text { Any type of student government } \\
\text { or council }\end{array}$ & $17 \%$ & $7 \%$ & $9 \%$ \\
\hline & $\begin{array}{l}\text { Environmental awareness or action } \\
\text { group }\end{array}$ & $16 \%$ & $2 \%$ & $10 \%$ \\
\hline & $\begin{array}{l}\text { Providing tutoring organized by the } \\
\text { college or university }\end{array}$ & $21 \%$ & $4 \%$ & $12 \%$ \\
\hline & Student judicial council or board & $6 \%$ & $2 \%$ & $3 \%$ \\
\hline & Leadership program or academy & $20 \%$ & $5 \%$ & $11 \%$ \\
\hline & $\begin{array}{l}\text { ROTC (Reserve Officers Training } \\
\text { Corp) }\end{array}$ & $5 \%$ & $2 \%$ & $3 \%$ \\
\hline & Varsity athletic team & $14 \%$ & $3 \%$ & $8 \%$ \\
\hline & Social fraternity or sorority & $22 \%$ & $10 \%$ & $14 \%$ \\
\hline & On-campus religious organization & $29 \%$ & $5 \%$ & $17 \%$ \\
\hline & Participated in at least one (10 total) & $68 \%$ & $25 \%$ & $49 \%$ \\
\hline & $\begin{array}{l}\text { Average \# different types of } \\
\text { experiences per respondent }(10 \text { total })\end{array}$ & 1.6 & 0.4 & 0.9 \\
\hline \multirow{2}{*}{ 胥 } & Participated in at least one ( 15 total) & $88 \%$ & $34 \%$ & $65 \%$ \\
\hline & $\begin{array}{l}\text { Average \# different types of experienc- } \\
\text { es per respondent ( } 15 \text { total) }\end{array}$ & 3.1 & 0.7 & 1.7 \\
\hline
\end{tabular}

Note. Percent of respondents who participated in each activity. 


\section{Ethical Development}

Table 7 presents data about ethical development. It includes all three constructs of knowledge of ethics, ethical reasoning, and ethical behavior.

Knowledge of ethics. Our SEED Survey includes five FE-style ethics items. About a third of respondents (31\%) correctly answered three items, while just $9 \%$ answered them all correctly.

Ethical reasoning. The average PI (Personal Interest), MN (Maintaining Norms), P (Post-conventional), and N2 scores of the study sample are 28.1, 33.0, 32.7, and 32.2, respectively. These scores are consistent with national norms (see Section 4.4).

Ethical behavior. Students report various levels of engagement in the positive ethical behaviors included on our SEED Survey. Sixty-two percent participated in volunteer service projects, $35 \%$ participated in $\mathrm{K}-12$ outreach, and $11 \%$ took an engineering class because of a service component. Seventy-two percent report engaging in at least one of the positive ethical behaviors on the SEED Survey.

TABLE 7

Ethical Development

\begin{tabular}{|c|c|c|}
\hline \multirow{6}{*}{$\begin{array}{l}\text { Knowledge } \\
\text { of ethics }\end{array}$} & Correctly answered five FE-style ethics items & $9 \%$ \\
\hline & Correctly answered four FE-style ethics items & $27 \%$ \\
\hline & Correctly answered three FE-style ethics items & $31 \%$ \\
\hline & Correctly answered two FE-style ethics items & $22 \%$ \\
\hline & Correctly answered one FE-style ethics items & $9 \%$ \\
\hline & Correctly answered zero FE-style ethics items & $2 \%$ \\
\hline \multirow{4}{*}{$\begin{array}{l}\text { Ethical } \\
\text { reasoning }\end{array}$} & PI score (average and standard deviation) & $28.1 \pm 12.83$ \\
\hline & MN score (average and standard deviation) & $33.0 \pm 13.97$ \\
\hline & P score (average and standard deviation) & $32.7 \pm 15.33$ \\
\hline & N2 score (average and standard deviation) & $32.2 \pm 14.35$ \\
\hline \multirow{6}{*}{$\begin{array}{l}\text { Positive } \\
\text { ethical } \\
\text { behavior }\end{array}$} & Took engineering class because of service component & $11 \%$ \\
\hline & Took non-engineering class because of service component & $15 \%$ \\
\hline & Participated in K-12 outreach & $35 \%$ \\
\hline & Participated in volunteer service projects & $62 \%$ \\
\hline & Assisted professor on volunteer service projects & $21 \%$ \\
\hline & Engaged in at least one of above positive ethical behaviors & $72 \%$ \\
\hline \multirow{8}{*}{$\begin{array}{l}\text { Negative } \\
\text { ethical } \\
\text { behavior }\end{array}$} & Cheated on tests & $24 \%$ \\
\hline & Cheated on problem sets & $45 \%$ \\
\hline & Cheated on lab reports & $20 \%$ \\
\hline & Cheated on writing assignments & $7 \%$ \\
\hline & Took advantage of group members & $21 \%$ \\
\hline & Lied to a professor about academic work & $14 \%$ \\
\hline & Knew about cheating by another student and did not report it & $64 \%$ \\
\hline & Engaged in at least one of above negative ethical behaviors & $79 \%$ \\
\hline
\end{tabular}

Note. Percent of respondents marking each item. 
Negative ethical behavior also varies, and for our sample it ranges from $7 \%$ who cheated on writing assignments to $45 \%$ who cheated on problem sets to $64 \%$ who knew about cheating by another student and did not report it. Overall, seventy-nine percent report cheating in some way while they have been in college, a proportion similar to other findings that more than $80 \%$ of engineering students report cheating (Carpenter, Harding, Finelli, Montgomery, \& Passow, 2006; McCabe, 1997).

\section{Summary and Discussion}

It is vital that the undergraduate educational experience promote engineering students' ethical development. Graduates entering the engineering profession must not only be prepared to follow and abide by professional codes of ethics, but they must also be able to grapple with more complex ethical dilemmas that arise from understanding and considering ways in which their work will affect the world. As technology continues to advance, those ethical dilemmas will become more complex (Sheppard, et al., 2009), making the need for effective ethics instruction even more pronounced.

Despite the importance of ethics instruction in engineering, there has been little systematic research conducted on the topic. In this paper, we present descriptive data from our Study of Engineering Ethical Development (SEED) Survey to address three research questions:

- What is the quantity of curricular and co-curricular experiences related to ethics in which students are engaged?

- What is the quality of those experiences?

- What is the level of students' ethical development?

\section{Curricular and Co-curricular Experiences}

Our data demonstrate that the quantity (i.e., variety and number) of ethics-related experiences to which students are exposed is quite high. Students experience formal curricular activities in a variety of settings and pedagogies, including introductory engineering courses as well as out-of-class workshops and non-engineering courses, and they participate in a variety of engineering-based and non-engineering based co-curricular activities. They also engage in a high number of these activities. Respondents to our SEED Survey report participating in almost six different types of formal curricular experiences and three co-curricular experiences related to ethics.

The quality of students' curricular and co-curricular experiences is also high. Almost half of the respondents report participating in cognitive activities aligned with the highest level of Bloom's taxonomy in their formal curricular experiences. More than one-third of the respondents acted as a leader for at least one co-curricular activity, and nearly twothirds participated in volunteer service sponsored by the co-curricular group.

Our findings suggest some important implications for the formal curriculum as well as the co-curriculum. Besides introductory engineering courses, common settings for ethics instruction in the formal curriculum include out-of-class workshops and non-engineering classes. Thus, students are likely to receive a great deal of their ethics instruction either in the first year (when faculty may be limited to more straightforward discussions or less complex dilemmas than in later years because of students' limited technical or professional understanding of engineering) or in non-engineering classes (when instruction is likely to be unconnected to the engineering discipline, and engineering faculty are likely to have limited control over the content of the instruction). Engineering courses could be 
designed to include ethics instruction throughout the curriculum, since these experiences could provide opportunities to teach about ethics in complex ways and to directly relate professional ethics and the technical content which students are learning.

The range of pedagogies with which students report having ethics instruction is quite varied-including lectures and presentations from multiple sources, role-playing activities, games, and online modules - and students report receiving high quality instruction. This suggests an encouraging degree of innovation in ethics instruction, and it highlights the importance of supporting faculty as they incorporate different types of ethics instruction and learn about other pedagogies. Institutional support for even more varied approaches that foster high-quality experiences could further promote students' ethical development.

As most students do participate in co-curricular activities that have an ethics component, our research highlights the potential for better leveraging students' co-curricular experiences. Students report that they learn and think critically about ethics through their co-curricular involvement (Burt, et al., 2011), but they note that those experiences often happen with little connection to formal curricula and with limited faculty support. These experiences could have more influence if they were integrated into the formal curriculum or if faculty or other campus leaders participated in or served as advisor for student organizations. Faculty advisors could also help students connect issues they encounter in their organizations with professional engineering ethics and could encourage and support critical thinking and discussions around those connections.

\section{Ethical Development}

We present multiple measures of students' ethical development, and our data is suggestive of ways to improve the undergraduate curriculum. Students' knowledge of ethics is surprisingly low. We previously reported (Hosapple, et al., 2012) that students describe their ethics instruction as comprising primarily black-and-white discussions, and since the FE-style ethics items on our SEED Survey focus on understanding professional codes of ethics, we are surprised that students only answer $60 \%$ of these items correctly, on average. For whatever reason, there is a disconnect between our assessment of students' knowledge of ethics and their ethics instruction, and ethics instruction could better emphasize this aspect of the curriculum.

Although the ethical reasoning levels for our sample fall within the range of scores typical for college students, they are at the low ends of those ranges, suggesting that engineering students' levels of ethical reasoning are lower than their peers in other fields. This is the first U.S. assessment of engineering students' ethical reasoning, and these results, like those for the knowledge of ethics, suggest that there is significant room for improvement. While these scores could mean that engineering students enter college with lower levels of ethical reasoning, they could also mean that other fields of study educate their students in a way that better promotes the development of ethical reasoning. Engineering educators should look to other disciplines for successful methods of instruction that can be effectively applied to engineering ethics education.

In our study, we find that many students participate in positive ethical behavior. Seventy-two percent of students report engaging in one of the positive ethical behaviors of our SEED Survey, and more than half participated in volunteer service projects. This suggests that students find important outlets for engaging in positive ethical behavior. This is further evidenced in that $11 \%$ and $15 \%$ of our sample has enrolled in an engineering and non-engineering course, respectively, specifically because of the service component. It 
underscores the potential to explicitly connect these positive ethical behaviors to activities of the engineering profession, thereby helping students understand the ways that their positive behavior can be a part of their identities as professional engineers.

Measures of negative ethical behavior are less encouraging. Almost $80 \%$ of students report having engaged in at least one of the seven cheating behaviors on our SEED Survey. This signifies that the emphasis being placed on academic integrity during discussions of ethics (an emphasis noted by students and faculty alike (Holsapple, et al., 2012)) may not be having a strong enough impact. These high rates of negative ethical behavior are also concerning because such behavior can dramatically affect the learning of students engaging in it. If large numbers of students cheat on tests, the validity of those tests as assessment instruments is at stake. Further, three of the negative ethical behaviors on our SEED Survey (taking advantage of group members, lying to professors, and knowing about but not reporting cheating by other students) go beyond typical measures of cheating, and the high number of students who report participating in these behaviors points to a need for wider conceptualizations of what constitutes academic dishonesty and negative ethical behavior.

Ethics instruction is a critical component of students' undergraduate engineering education, yet little research has been done to understand how ethics is being included in the formal curriculum, how it is included in the co-curriculum, and how it might affect students' ethical development. Our exploratory study contributes to engineering education research and practice by describing the current state of engineering students' curricular and co-curricular experiences and ethical development. The data we present offer a snapshot of ethics education in the U.S. and demonstrate the wide variety of ways in which students receive ethics instruction. The data also highlight opportunities to improve the undergraduate curriculum, to integrate ethics instruction throughout the formal curriculum, and to connect students' formal curricular experiences with their co-curricular involvement and inclination to engage in positive ethical behaviors. A more comprehensive analysis of the SEED survey data, planned for later publications, will provide more detailed insight.

\section{ACKNOWLEDGMENTS}

This material is based upon work supported by the National Science Foundation under Grant Numbers 0647460, 0647532, and 0647929. Any opinions, findings, and conclusions or recommendations expressed in this material are those of the author(s) and do not necessarily reflect the views of the National Science Foundation. We gratefully acknowledge the support of the 19 SEED partner institutions.

\section{REFERENCES}

ABET (2009). Criteria for accrediting engineering programs: Effective for evaluations during the 2010-2011 Accreditation Cycle. Retrieved from www.abet.org/forms.shtml

Adams, M., \& Zhou-McGovern, Y. (1994). The sociomoral development of undergraduates in a "social diversity" course: Developmental theory, research, and instructional applications. Paper presented at the annual meeting of the American Educational Research Association, New Orleans, LA. 
Adams, R., Fortenberry, S., Haghighi, K., Imbrie, P. K., Jamieson, L., Lohmann, J., Reed-Rhoads, T., \& Smith, K. (2006). Special Report: The research agenda for the new discipline of engineering education. Journal of Engineering Education, 95(4), 259-261.

American Association of Colleges and Universities (2009). Trends and emerging practices in undergraduate education. Retrieved from www.aacu.org/membership/membersurvey.cfm

American Society of Engineering Education. (2010). Profiles of engineering and engineering technology college. Retrieved from http://profiles.asee.org

Anderson, L. W., \& Krathwohl, D. R. (2001). A taxonomy for learning, teaching, and assessing: A revision of Bloom's taxonomy of educational objectives. New York, NY: Longman Publishing Group.

Association of German Engineers (VDI). (2002). Fundamentals of engineering ethics. Retrieved from www.vdi.de/fileadmin/media/content/hg/17.pdf

Astin, A. (1993). What matters in college? Four critical years revisited. San Francisco, CA: JosseyBass.

Bandura, A., Millard, M., Peluso, E. A., \& Ortman, N. (2000). Effects of peer education training on peer educators: Leadership, self-esteem, health knowledge, and health behaviors. Journal of College Student Development, 41(5), 471-478.

Bebeau, M.J. (2002). The defining issues test and the four component model: Contributions to professional education. Journal of Moral Education, 31(3), 271-295.

Bebeau, M. J., \& Thoma, S. J. (1999). "Intermediate" concepts and the connection to moral education. Educational Psychology Review, 11(4), 343-360.

Berger, J. B., \&Milem, J. F. (1999). The role of student involvement and perceptions of integration in a causal model of student persistence. Research in Higher Education, 40(6), 641-664.

Bernacki, M. L., \& Jaeger, E. (2008). Exploring the impact of service-learning on moral development and moral orientation. Michigan Journal of Community Service Learning, 14(2), 5-15.

Bird, S. J. (2003). Integrating ethics education at all levels-Ethics as a core competency. Emerging technologies and ethical issues in engineering (pp. 125-131). Washington, DC: National Academies Press.

Bloom, B. S. (1956). Taxonomy of educational objectives. Handbook I: Cognitive domain. Handbook II: Affective domain. New York, NY: David McKay.

Bonawitz, M. F. (2002). Analysis and comparison of the moral development of students required to graduate with an ethics course (Unpublished doctoral dissertation) Florida International University, Miami, FL.

Boss, J. A. (1994). The effect of community service work on the moral development of college ethics students. Journal of Moral Education, 23(2). 183-198.

Burt, B.A., Carpenter, D. D., Finelli, C. J., Harding, T. S., Sutkus, J. A., Holsapple, M. A., Bielby, R. M., \& Ra, E. (2011). Outcomes of engaging engineering undergraduates in co-curricular experiences. Proceedings of the ASEE Annual Conference and Exposition, Vancouver, Canada.

Canadian Engineering Qualifications Board. (2001). Guideline on the code of ethics. Retrieved from www.engineerscanada.ca/e/files/guideline_code_with.pdf

Carpenter, D. D., Harding, T. S., Finelli, C. J., Montgomery, S. M., \& Passow, H. J. (2006). Engineering students' perceptions of and attitudes towards cheating. Journal of Engineering Education, 95(3), 181-194. 
Chen, H. L., Lattuca, L. R., \& Hamilton, E. R. (2008). Conceptualizing engagement: Contributions of faculty to student engagement in engineering. Journal of Engineering Education, 97(3), 339-353.

Colby, A., \& Sullivan, W. M. (2008). Ethics teaching in undergraduate engineering education. Journal of Engineering Education, 97(3), 327-338.

Eagen, M. K., \& Jaeger, A. J. (2008). Closing the gate: Part-time faculty instruction in gatekeeper courses and first-year persistence. New Directions for Teaching and Learning, 115, 39-54.

Engineers Australia (2010). Code of ethics. Retrieved from www.engineersaustralia.org.au/ethics

Ericsson, K. A., \& Simon, H. A. (1993). Protocol analysis: Verbal reports as data. Revised edition. Cambridge, MA:The MIT Press.

Etter, B. K., Harding, T. S., Finelli, C. J., \& Carpenter, D. D. (2004). The role of moral philosophy in promoting academic integrity among engineering students. Proceedings of the $34^{\text {th }}$ Frontiers in Education Conference, Savannah, GA.

Falls, M. D. (2009). Psychological sense of community and retention: Rethinking the first-year experience of students in STEM (Unpublished doctoral dissertation). University of Central Florida, Orlando, FL.

Finelli, C. J., Harding, T. S., Carpenter, D. D., \& Mayhew, M. J. (2007). Academic integrity among engineering undergraduates: Seven years of research. Proceedings of the 2007 ASEE Annual Conference E' Exposition, Honolulu, HI.

Flowers, L. A. (2004). Examining the effects of student involvement on African American college student development. Journal of College Student Development, 45(6), 633-654.

Harding, T. S., Carpenter, D. D., \& Finelli, C. J. (2012). An exploratory investigation of the ethical behavior of engineering undergraduates. Journal of Engineering Education, 101(2), 346-374.

Harding, T. S., Carpenter, D. D., Finelli, C. J., \& Passow, H. J. (2004a). Does academic dishonesty relate to unethical behavior in professional practice? An exploratory study. Science and Engineering Ethics. 10(2), 311-324.

Harding, T. S., Carpenter, D. D., Finelli, C. J., \& Passow, H. J. (2004b). The influence of academic dishonesty on ethical decision making in the workplace: A study of engineering students. Proceedings of the ASEE Annual Conference and Exposition, Salt Lake City, UT.

Harding, T. S., Finelli, C. J., \& Carpenter, D. D. (2006). Cheating in college and its influence on ethical behavior in professional practice. Proceedings of the 2006 ASEE Annual Conference E Exposition, Chicago, IL.

Harris, C. E. (2003). Methodologies for case studies in engineering ethics. Emerging technologies and ethical issues in engineering (pp. 79-93). Washington, DC: National Academies Press.

Haws, D. R. (2001). Ethics instruction in engineering education: A (mini) meta-analysis. Journal of Engineering Education, 90(2), 223-229.

Herkert, J. R. (2003). Microethics, macroethics, and professional engineering societies. In Emerging technologies and ethical issues in engineering (pp. 107-166). Washington, DC: National Academies Press.

Holsapple, M. A. Carpenter, D. D., Finelli, C. J., Sutkus, J. A., Harding, T. S., \& Walczak, K. (2010). Understanding the differences between faculty and administrator goals and students' 
experiences with ethics education. Proceedings of the 2010 ASEE Annual Conference E' Exposition, Louisville, $K Y$.

Holsapple, M. A., Carpenter, D. D., Sutkus, J. A., Finelli, C. J., \& Harding, T. S. (2012). Framing faculty and student discrepancies in engineering ethics education delivery. Journal of Engineering Education, 101(2).

Holsapple, M. A., Finelli, C. J., Carpenter, D. D., Harding, T. S., \& Sutkus, J. A, (2009). Work in progress: A mixed-methods approach to developing an instrument measuring engineering students' positive ethical behavioral outcomes. Proceedings of the $39^{\text {th }}$ Frontiers in Education Conference, San Antonio, TX.

Hoyt, B. R. (2008). A research study investigating the impact of service-learning on ethical decision making. In M. A. Bowen, S. H. Billig, \& B. A. Holland (Eds.), Scholarship for sustaining service-learning and civic engagement (pp. 185-206). Charlotte, NC: IAP-Information Age Publishing.

Hughes, R., \& Pace, C. R. (2003). Using NSSE to study student retention and withdrawal. Assessment Update, 15(4), 1-2.

Hurtado, S., Mayhew, M. J., \& Engberg, M. E. (2003). How diversity courses affect the development of moral reasoning. Paper presented at the Annual Meeting of the Association for the Study of Higher Education, Portland, OR.

Jaeger, A. J., \& Hinz, D. (2008). The effects of part-time faculty on first semester freshman retention: A predictive model using logistic regression. Journal of College Student Retention, 10(3), 265-286.

Japan Society of Civil Engineers (1999). Code of ethics for civil engineers. Retrieved from www. jsce-int.org/ethics/code_of_ethics.shtml

Keefer, M., \& Ashley, K. D. (2001). Case-based approaches to professional ethics: A systematic comparison of students' and ethicists' moral reasoning. Journal of Moral Reasoning, 30(4), 377-398.

King, P. M., \& Mayhew, M. J. (2002) Moral judgement development in higher education: insights from the Defining Issues Test. Journal of Moral Education, 31(3), 247-270.

Kuh, G. D. (1995). The other curriculum: Out-of-class experiences associated with student learning and personal development. Journal of Higher Education, 66(2), 123-155.

Kuh, G. D. (2001). Assessing what really matters to student learning: Inside the National Survey of Student Engagement. Change, 33(3), 10-17, 66.

Kuh, G. D. (2003). What we're learning about student engagement from NSSE. Change, 35(2), 24-32.

Kuh, G. D. (2009). The National Survey of Student Engagement: Conceptual and empirical foundations. In R. Gonyea \& G. Kuh (Eds.), Using student engagement data in institutional research. New Directions for Institutional Research, 141 (pp. 5-20). San Francisco, CA: Jossey-Bass.

Kuh, G. D., Cruce, T.M., Shoup, R., Kinzie, J., \& Gonyea, R. M. (2008). Unmasking the effects of student engagement on college grades and persistence. Journal of Higher Education, 79(5), 540-563.

Lincoln, T. D. (2009). The seminary experience: Conceptual worlds of first-career and second-career seminarians (Unpublished doctoral dissertation). University of Texas at Austin. 
Lovik, E. G., \& Volkwein, J. F. (2010). The impact of organizational features and student experiences on spiritual development during the first year of college. Paper presented at the annual conference of the Association for the Study of Higher Education, Indianapolis, IN.

Mayhew, M. J., \& King, P. M. (2008). How curricular content and pedagogical strategies affect moral reasoning development in college students. Journal of Moral Development, 37(1), 17-40.

Mayhew, M. J., Seifert, T. A., \& Pascarella, E. T. (2010). A multi-institutional assessment of moral reasoning development among first-year students. Review of Higher Education, 33(3), 357-390.

McCabe, D. (1997). Classroom cheating among natural science and engineering majors. Science and Engineering Ethics, 3(4), 433-445.

McCabe, D. L., Trevino, L. K., \& Butterfield, K. D. (2001). Cheating in academic institutions: A decade of research. Ethics and Behavior, 11(3), 219-232.

Murphy, C. (2010). Residential learning outcomes: Analysis using the college student experiences questionnaire at a large public research university (Unpublished doctoral dissertation). University of South Florida, Tampa, FL.

National Academy of Engineering. (2003). Emerging technologies and ethical issues in engineering. Washington, DC: National Academies Press.

National Academy of Engineering. (2004). The engineer of 2020: Visions of engineering in the new century. Washington, DC: National Academies Press.

National Council of Examiners for Engineering and Surveying. (2010). Fundamentals of engineering exam. Retrieved from www.ncees.org/Exams/FE_exam.php

National Science Foundation. (2006). Investing in America's future-National Science Foundation Strategic Plan FY 2006-2011. Retrieved from www.nsf.gov/publications/pub_summ. jsp?ods_key=nsf0648

National Society of Professional Engineers. (2010). NSPE code of ethics for engineers. Retrieved from www.nspe.org/Ethics/CodeofEthics/index.html

Newberry, B. (2004). The dilemma of ethics in engineering education. Science and Engineering Ethics, 10(2), 343-351.

Pace, C. R. (1984). Measuring the quality of college student experiences. An account of the development and use of the college student experiences questionnaire. Los Angeles, CA: Higher Education Research Institute.

Pace, C. R. (1990). The undergraduates: A report of their activities and college experiences in the 1980s. Los Angeles, CA: Center for the Study of Evaluation, UCLA Graduate School of Education.

Pascarella, E. T., Seifert, T. A., \& Blaich, C. (2009). Validation of the NSSE Benchmarks and deep approaches to learning against liberal arts outcomes. Iowa City, IA: University of Iowa Center for Research on Undergraduate Education.

Penner, L. A., Dovidio, J. F., Piliavin, J. A. \& Schroeder, D. A. (2005). Prosocial behavior: Multilevel perspectives. Annual Review of Psychology, 56, 365-392.

Pike, G. R. (2003). Membership in a fraternity or sorority, student engagement, and educational outcomes at AAU public research universities. Journal of College Student Development, 44(3), 369-382. 
Pike, G. R., \& Kuh, G.D. (2005). First- and second-generation college students: A comparison of their engagement and intellectual development. Journal of Higher Education, 76(3), 276-300.

Potter, M. C., Bennett, M., Case, E., Gilliland, D., Hatfield, F., Heiden, P., Root, R., Weinberg, B. \& Zapp, R. (2008). Fundamentals of Engineering Review (M. R. Gruender, Ed.). Okemos, MI: Meridian Press, Inc.

Prados, J. W., Peterson, G. D., \& Lattuca, L. R. (2005). Quality assurance of engineering education through accreditation: The impact of Engineering Criteria 2000 and its global influence. Journal of Engineering Education, 94(1), 165-184.

Pratt, S. B. (2001). Moral development in college students engaged in community service learning: A Justice-Care perspective (Unpublished doctoral dissertation). Boston College, Boston, MA.

Reason, R. D. (2009). Understanding the development of the whole person. Journal of College Student Development, 50, 573-575.

Reason, R. D., Cox, B. E., Quaye, B. R. L., \& Terenzini, P. T. (2010). Faculty and institutional factors that promote student encounters with difference in first-year courses. Review of Higher Education, 33(3), 391-414.

Reason, R. D., Terenzini, P.T., \& Domingo, R. J. (2006). First things first: Developing academic competence in the first year of college. Research in Higher Education, 47(2), 149-175.

Reason, R. D., Terenzini, P. T., \& Domingo, R. J. (2007). Developing social and personal competence in the first year of college. Review of Higher Education, 30(3), 271-299.

Rest, J. R., Narvaez, D., Thoma, S. J., \& Bebeau, M. J. (2000) A Neo-Kohlbergian approach to morality research. Journal of Moral Education, 29(4), 381-395.

Rest, J., Narvaez, D., Bebeau, M. \& Thoma, S. (1999). A Neo-Kohlbergian approach:The DIT and schema Theory. Educational Psychology Review, 11(4), 291-324.

Royal Academy of Engineering. (n.d.). Statement of ethical principles. Retrieved from www.engc. org.uk/ecukdocuments/internet/document $\% 20$ library/Statement $\% 20$ of $\% 20$ Ethical $\% 20$ Principles.pdf

Self, D. J., \& Ellison E. M. (1998). Teaching engineering ethics: Assessment of its influence on moral reasoning skills. Journal of Engineering Education, 87(1), 29-34.

Sheppard, S., Macatangay, K., Colby, A., \& Sullivan, W. (2009). Educating engineers. Design for the future of the Field. Carnegie Foundation for the Advancement of Teaching. San Francisco, CA:Jossey-Bass.

Sutkus, J. A., Carpenter, D. D., Finelli, C. J., \& Harding, T. S. (2008). Work-in-progress: Building the Survey of Engineering Ethical Development (SEED) instrument. Proceedings of the 38th IEEE/ASEE Frontiers in Education Conference, Saratoga, NY.

Sutkus, J. A., Finelli, C. J., Carpenter, D. D., \& Harding, T. S. (2009). An examination of student experiences related to engineering ethics: Initial findings. Proceedings of the 2009 ASEE Annual Conference E' Exposition, Austin, TX.

Terenzini, P.T., \& Reason, R. D. (2005). Parsing the first year of college: Rethinking the effects of college on students. Paper presented at the Annual Conference of the Association for the Study of Higher Education, Philadelphia, PA.

Tinto, V. (1993) Leaving college: Rethinking the causes and cures of student attrition. ( $2^{\text {nd }}$ ed.). Chicago, IL: University of Chicago Press. 
Van Someren, M. W., Barnard, Y. F., \& Sandberg, J. A. C. (1994). The think aloud method: A practical guide to modeling cognitive processes. San Diego, CA: Academic Press.

Walczak, K., Finelli, C. J., Holsapple, M. A., Sutkus, J. A., Harding, T. S., \& Carpenter, D. D. (2010). Institutional obstacles to integrating ethics into the curriculum and strategies for overcoming them. Proceedings of the 2010 ASEE Annual Conference E' Exposition, Louisville, KY.

Wolf-Wendel, L., Ward, K., \& Kinzie, J. (2009). A tangled web of terms: The overlap and unique contribution of involvement, engagement, and integration to understanding college student success. Journal of College Student Development, 50(4), 407-428.

Wright, R. L. (2001). The relationship of community service and the moral judgment of freshmen at a Christian college (Unpublished doctoral dissertation). Kansas State University, Manhattan, KS.

\section{AuTHORS}

Cynthia J. Finelli is a research associate professor of Engineering Education and director of the Center for Research on Learning and Teaching in Engineering, University of Michigan, 208 Gorguze Family Laboratory, 2609 Draper Drive, Ann Arbor, MI, 48109; cfinelli@umich.edu.

Matthew A. Holsapple is a doctoral candidate at the Center for the Study of Higher and Postsecondary Education, University of Michigan, 610 E. University Avenue, Ann Arbor, MI, 48109; mapple@umich.edu.

Eunjong Ra is a policy analyst, Ministry of Education, Science \& Technology, Central Government Complex, 77-6, Sejong-no, Jong-no, Seoul, Republic of Korea, 110-760; eun47@mest.go.kr.

Rob M. Bielby is a doctoral student at the Center for the Study of Higher and Postsecondary Education, University of Michigan, 610 E. University Avenue, Ann Arbor, MI, 48109; rbiebly@umich.edu.

Brian A. Burt is a doctoral candidate at the Center for the Study of Higher and Postsecondary Education, University of Michigan, 610 E. University Avenue, Ann Arbor, MI, 48109; burtbri@umich.edu.

Trevor S. Harding is chair and professor of Materials Engineering, California Polytechnic State University, 1 Grand Avenue, San Luis Obispo, CA 9407; tharding@ calpoly.edu.

Donald D. Carpenter is an associate professor of Civil Engineering and director of Assessment, Lawrence Technological University, 21000 W. Ten Mile Rd, Southfield, MI, 48075; dcarpente@1tu.edu

Janel A. Sutkus is director of Institutional Research and Analysis, Carnegie Mellon University, 5000 Forbes Avenue, Pittsburgh, PA, 15213; jsutkus@cmu.edu. 